International

Medical Society

http://imedicalsociety.org

\title{
Zika Virus:
}

\section{Outcome and Follow up in Brazil's Northeast Women

\author{
Cristiano Nogueira Marques ${ }^{1}$, Arthur Rafhael Amorim Alves Esmeraldo ${ }^{1}$, \\ Francisca Patricia de Melo Santos Leite ${ }^{1}$, Dábylla Cynthia Carvalho Bezerra ${ }^{1}$
}

\section{Abstract}

The World Health Organization (WHO) declared a Public Health Emergency of Inter- national Concern in response to a cluster of microcephaly (restricted fetal brain and skull growth) and neurological disorders likely associated with Zika virus. A Short Communication that focus on The exponential increase and extreme severity of Zika virus (ZIKV), contrasting with evidence that Include: discovery or development of new information's, novelty in modeling scientific, elucidation of mechanisms editorials and channels of information.

Keywords

Zika Viru; Public Health; Microcephaly.

Zika virus (ZIKV) belongs to the genus Flavivirus in the family Flaviviridae. Currently, the genus comprises 53 virus species, which are transmitted by the bite of mosquitoes ( 27 species), ticks (12 species), or no known arthropod vector (14 species) (Song et al., 2017).

Dengue has been an endemic disease in Brazil for many decades; however, an unparalleled epidemic of diverse arboviruses, such as Zika and chikungunya, emerged as a new public health risk in 2015 (Guerra - Gomes et al., 2017).

Discovered in Uganda in 1947, ZIKV was confined for the first 60 years to an equatorial zone across Africa and Asia. Outside this zone, however, it first emerged in Yap Island in 2007, spread eastward to French Polynesia and other Pacific Islands in 2013-2014, reached Latin America in 2015, and disseminated further to North America in 2016 (Song et al., 2017).
1 Faculty of Medicine, Federal University of Cariri,UFCA, Ceará, Brazil.

\section{Contact information:}

Modesto Leite Rolim Neto.

Address: Faculty of Medicine, Federal University of Cariri (UFCA), 284, Divine Savior Street, Downtown, Barbalha, Ceará 63180000, Brazil.

Tel: +5588 999042979 .

झ modestorolim@yahoo.com.br 
The exponential increase and extreme severity of ZIKV neurological disorders, congenital Zika syndrome in newborns and Guillain-Barré syndrome in adults, contrasting with evidence since its first isolation in humans in 1954 in a young girl in Eastern Nigeria (Mac-Namara 1954) of mild disease and non-life threatening symptoms, turned this new disease into one of the highest priorities of global public health concern (Possas et al., 2017).

Zika virus, a mosquito-borne flavivirus that can cause rash with fever, emerged in the Region of the Americas on Easter Island, Chile, in 2014 and in northeast Brazil in 2015 (Ikejezie et al., 2017).

On February 1, 2016, the World Health Organization (WHO) declared a Public Health Emergency of International Concern in response to a cluster of microcephaly (restricted fetal brain and skull growth) and neurological disorders likely associated with Zika virus. Although previous Zika outbreaks were considered benign, a dramatic rise in babies born with microcephaly in poor communities in northeast Brazil prompted investigation of infectious etiologies. By April 2016, scientists concluded that antenatal Zika infection causes miscarriage, stillbirth, and a range of neurological malformations including microcephaly, but also motor, ocular, and auditory changes (Rasanathan et al., 2017).

ZIKV is transmitted to humans primarily through the bite of infected mosquitoes, but it can also be passed from mother to child during pregnancy or spread through sexual contact, breastfeeding, or blood transfusion. The multiple modes of ZIKV transmission make it difficult to develop control strategies against the pathogen (Song et al., 2017).

The Zika epidemic, which involves cases of microcephaly and/or other alterations in the central nervous system associated with viral infection, affects women from a specific social class and region: poor women from Northeast Brazil. Seventy-two per cent of the babies born with the symptoms of Zika virus congenital syndrome in Brazil are born to women who live in the northeast states of Bahia, Paraíba,
Pernambuco, and Rio Grande do Norte. Simply referring to cases ignores the stories and the suffering, the anguish and the abandonment (Diniz, 2016a).

The geography of the epidemic mirrors the social inequalities of Brazilian society: until now, there have been no reports of affluent women giving birth to babies with Zika-related neurological disorders (Diniz, 2016b).

They are very similar - young, rural farmers or unemployed, with low levels of education, and dependent on health services and public transportation in order to be able to care for their infants, who have multiple impairments caused by the Zika virus. This was the first generation of pregnant women infected by the Zika virus in Brazil. Some of them were informed that their child had been affected by the virus during the ultrasound, at the same time that biomedical research was still drawing relational or causal hypotheses; they lived through moments in which they were neglected by both health assistance as well as science (Diniz, 2016a).

On November 18, 2016, WHO declared that Zika virus and associated complications remain a considerable public health challenge requiring long-term coordinated action, but no longer represent a Public Health Emergency of International Concern (Ikejezie et al., 2017).

To have a special child is a divine ordeal for some of them, with motherhood as a required condition for survival. There is a life-giving relationality between mothers and children which makes it easy for their lives to become subject- ed to the increasing demands for care: trips in improvised transportation from rural cities to Campina Grande; ten-hour daily trips to attend thirty-minute early stimulation sessions; waiting for "help" to feed the child, since many newborns struggle to breastfeed. The inherent relationship between ethics and maternal responsibility is exacerbated by the precarious lives of the women, not only by the vulnerability of the newborn. The truth is that they were already anonymous women before the epidemic. Poor and living 
in the Northeast, they survive a broad spectrum of regimes that make their lives precarious, with poverty the worst of them. The epidemic was a tragedy for unintelligible lives - the epidemiological surveillance numbers consider the children to be cases for notification or confirmation, yet they are silent about the women (Diniz, 2016a).

However, while biomedical research requires time to establish explanations, an epidemic demands immediate responses. Brazilian women are facing an increase in Zika infections and have urgent needs that cannot wait for the results of ongoing biomedical investigations (Diniz, 2016b).

A second generation of pregnant women infected by the Zika virus is now coming to prenatal clinics in Campina Grande. There is an important difference between them and the first generation a year ago, the unfamiliarity with the circulation of the virus made women witness the discovery of the effects of the virus in their own bodies. The women from the second generation are aware of the virus since the information about the risk of the epidemic is available to the public, though uncertain: Pedro I Hospital sees children with the congenital syndrome from 22 cities in Paraíba. The second generation of these women are living through a more tormented experience: some women prefer not to undergo the prenatal routine if they present symptoms of Zika infection; some refuse to have ultrasounds, a tendency that has already been identified among other women. They choose not to know because there is nothing they can do about it: without the right to terminate the pregnancy and with many scientific uncertainties, an early diagnosis is simply psychological torture (Diniz, 2016a).

Women have the right to decide to be freed of psychological torture imposed by the epidemic. It is not the fetus's future impairments or the "extreme negative consequences for the families affected" that moves our demand, but the urgency to protect women's rights in the epidemic (Diniz et al., 2016c).
For the women of the second generation infected by the Zika virus, it is necessary to ensure access to information and family planning, with long-term contraceptive methods (currently not provided by Brazilian health policy), in addition to the right to terminate the pregnancy. Access to information and family planning are two health principles and rights provided by the 1988 Brazilian Constitution. The women of the first generation have unmet needs for social protection, the most urgent of which are conditions for survival and transportation to health care facilities. There is ongoing intersectional discrimination in the way the epidemic crosses the lives of these women: they were already poor, Northeast inhabitants, with low levels of education, and weakly integrated into the labor world; now, they are also caregivers of children with needs that are not protected by the Brazilian state (Diniz, 2016a).

There is no approved vaccine for Zika virus. The primary methods of prevention are avoiding the bites of infected Aedes mosquitoes and reducing the risk of sexual trans- mission. Pregnant women should not travel to areas with active Zika virus transmission and should abstain from sex or use condoms for the duration of pregnancy if their partner has possible Zika virus exposure. Men and women who do not live in areas with active Zika virus transmission and who are planning to conceive in the near future should consider avoiding nonessential travel to areas with active transmission. If they have possible exposure, they should wait at least six months (for men) or at least eight weeks (for women) from symptom onset or last possible exposure before attempting conception (Igbinosa et al., 2017).

\section{References}

- Song, B-H., et al. Zika virus: History, epidemiology, transmission, and clinical presentation. J. Neuroimmunol, 2017.

- Ikejezie, J., et al. Zika Virus Transmission - Region of the Americas, May 15, 2015 - December 15, 2016. Morbidity and Mortality Weekly Report, 2017, v66, n12. 
- Rasanathan, J., et al. Engaging Human Rights in the Response to the Evolving Zika Virus Epidemic. AJPH, 2017, v107, n4.

- Diniz, D. Zika virus and women. Cad. Saúde Pública, Rio de Janeiro, 2016a, v32, n5.

- Diniz, D. Zika virus, women and ethics. Developing World Bioethics, 2016b, v16, n2.

- Diniz, D., et al. The Protection to Women's Fundamental Rights Violated by the Zika Virus Epidemic. Letters and responses, 2016c, v106, n8.

- Igbinosa, I., et al. Zika Virus: Common Questions and Answers. American Family Physician, 2017, v95, n8.

- Possas, C., et al. Zika puzzle in Brazil: peculiar conditions of viral introduction and dissemination - A Review. Men Inst Oswaldo Cruz, Rio de Janeiro, 2017, v112, n5.

- Guerra-Gomes, I., et al. Molecular and clinical epidemiological surveillance of dengue virus in Paraiba, Northeast Brazil. Rev Soc Bras Med Trop, 2017, v50, n1.

Publish in International Archives of Medicine

International Archives of Medicine is an open access journal publishing articles encompassing all aspects of medical science and clinical practice. IAM is considered a megajournal with independent sections on all areas of medicine. IAM is a really international journal with authors and board members from all around the world. The journal is widely indexed and classified Q2 in category Medicine. 